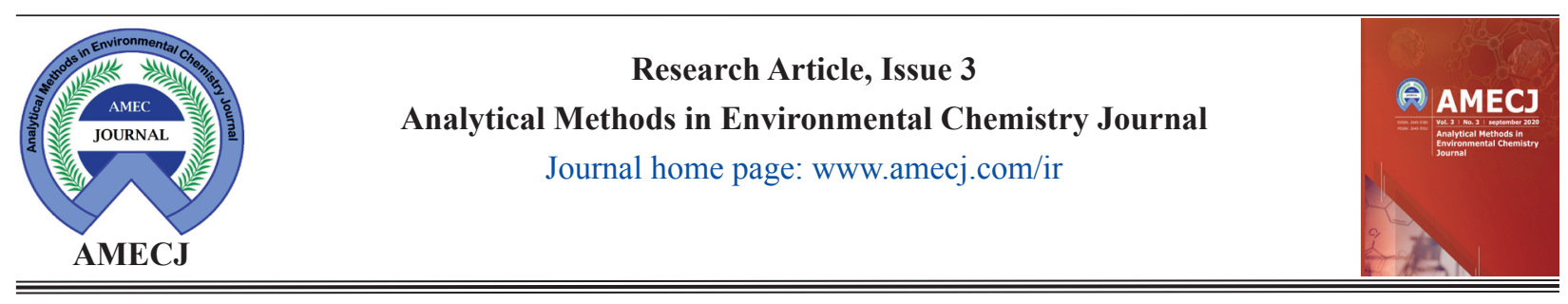

\title{
Speciation of chromium in blood samples based on dithioglycerol immobilized on carbon nanotube by dispersive micro solid phase bioextraction
}

\author{
Nafiseh Esmaeili a, Eskandar Kolvari a and Jamshid Rakhtshah ${ }^{\text {b,* }}$ \\ ${ }^{a,{ }^{*}}$ Department of chemistry, Faculty of Science, Semnan University, Semnan, Iran \\ b.* Department of Inorganic Chemistry, Faculty of Chemistry, University of Tabriz, Tabriz, Iran
}

\section{A R T I C L E I N F O :}

Received 5 Jun 2020

Revised form 3 Aug 2020

Accepted 27 Aug 2020

Available online 30 Sep 2020

Keywords:

Chromium, Speciation,

Blood sample,

Dithioglycerol immobilized on carbon nanotubes,

Dispersive micro solid phase

bioextraction

\begin{abstract}
A B S T R A C T
A novel method based on the synthesis of dithioglycerol immobilized on carbon nanotubes (CNTs@DTG) was used for speciation of chromium $\left(\mathrm{Cr}_{\mathrm{III}}\right.$ and $\left.\mathrm{Cr}_{\mathrm{VI}}\right)$ in human blood samples by dispersive micro solid-phase bioextraction (D- $\mu$-SPBE). By procedure, a mixture containing acetone and 1-octyl-3-methylimidazolium hexafluorophosphate ([OMIM] $\left.\left[\mathrm{PF}_{6}\right]\right)$ and CNTs@DTG were injected into $5 \mathrm{~mL}$ of standard and blood sample containing $1.0 \mu \mathrm{g} \mathrm{L}-1$ of $\mathrm{Cr}$ III and $\mathrm{Cr}_{\mathrm{VI}}$ which was diluted with DW up to $10 \mathrm{~mL}$ at optimized $\mathrm{pH}$. The $\mathrm{Cr}(\mathrm{VI})$ anions and $\mathrm{Cr}$ (III) cations were efficiently extracted by HS of CNTs@DTG at pH 2 and 6, respectively (HS.....Cr) and trapped into IL phase at the bottom of the conical tube. Then, $\mathrm{Cr}$ (III) and $\mathrm{Cr}(\mathrm{VI})$ ions were back-extracted from the IL/CNTs@DTG to the aqueous phase by changing $\mathrm{pH}$ for each of them before determined by electrothermal atomic absorption spectrometry (ETAAS). Total chromium was calculated by summarizing $\mathrm{Cr}_{\mathrm{III}}$ and $\mathrm{Cr}$ VI content. The enrichment factor (EF), linear range and limit of detection (LOD) were obtained 9.85, 0.12-3.88 $\mu \mathrm{g} \mathrm{L}^{-1}$ and $30 \mathrm{ng} \mathrm{L}^{-1}$, respectively. Validation of the methodology was confirmed with standard addition to real samples and ICP-Ms analysis.
\end{abstract}

\section{Introduction}

Heavy metals accumulate in different human tissues as non biodegradability property. Many of them enter to the human body from foods and waters and absorb them by the gastrointestinal system. Moreover, even with low concentration in the human biological matrix have a toxicological effect in human body and cause chromosomal aberration, cancer, and changes in DNA. The main source of chromium pollutants in the environment is chemical

Corresponding Author: Jamshid Rakhtshah

Email:jamshid_rakhtshah@yahoo.com

https://doi.org/10.24200/amecj.v3.i03.114 factories, steelworks and industrial electroplating. $[1,2]$. The chromium has two species $\left(\mathrm{Cr}_{\text {III }}\right.$ and $\mathrm{Cr}$ $\left.{ }_{\mathrm{VI}}\right)$ in the environment with different toxicity and physiological effects in humans. The metabolism of glucose, protein and lipids in the human body depend on $\mathrm{Cr}$ (III) compounds in humans [3-5]. But the $\mathrm{Cr}$ (VI) is toxic and causes cancer in humans. Due to the high oxidation of $\mathrm{Cr}$ (VI), it can be simply entered cells and damage the proteins and DNA of the nucleolus. Also, the Cr (VI) is harmful to different organs such as the lungs, liver and kidneys [6, 7]. The World Health Organization (WHO) reported the concentration chromium in water less than 2 
$\mu \mathrm{g} \mathrm{L}^{-1}$ and $50 \mu \mathrm{g} \mathrm{L}^{-1}$ as normal range and toxicity in waters [8]. Also, the national health company announced that the value of $0.1-1.7 \mu \mathrm{g} \mathrm{L}^{-1}$ and 0.24-1.8 $\mu \mathrm{g} \mathrm{L}^{-1}$ for normal chromium in blood and urine samples $[9,10]$. So, as different toxicity and exposure, the favorite and efficient procedure must be used for chromium speciation. Many efficient techniques such as inductively coupled plasma mass spectrometry [11], flame atomic absorption spectrometry (F-AAS) [12], inductively coupled plasma optical emission spectrometry (ICP-OES) [13], inductively coupled plasma-mass spectrometry (ICP-MS) [14], energy dispersive X-ray fluorescence spectrometry [15] and electrothermal atomic absorption spectrometry (ETAAS) [16] were used for chromium determination and speciation. However, the high cost of instrumental and difficulty matrix in human samples caused to use of these techniques with sample preparation methods. Recently, green analytical chemistry based on ionic liquids (ILs) as a simplification and authors reported miniaturization of the sample preparation with green solvent. Therefore, some of sample preparation procedures such as the liquid-liquid microextraction (LLME) [17], the solid-phase extraction (SPE) [18], the dispersive micro solid phase extraction [19] and the magnetic solid-phase extraction (MSPE) [20] applied as sample preparation. The ILs as an organic salt has various advantages such as low vapor pressure, thermal stability about $200-350{ }^{\circ} \mathrm{C}$, large viscosity, good extractability and separation phase [21]. The different adsorbents such as multi-walled carbon nanotubes (MWCNTs) [22], silica nanoparticles [23], MIL-101(Fe) and dithiocarbamate-modified magnetite nanoparticles [24], and fabrication of magnetic particles imprinted cellulose based biocomposites [25] were used for extraction and separation of chromium ions in a different matrix. In this study, the D- $\mu$-SPBE procedure was used to develop a new procedure based on CNTs@DTG adsorbent for the speciation of trace amount of $\mathrm{Cr}$ (III) and $\mathrm{Cr}(\mathrm{VI})$ in human blood samples. Experimental parameters were optimized for chromium speciation, and the performance of the proposed method was evaluated by ET-AAS. As a high efficient recovery, the $[\mathrm{OMIM}]\left[\mathrm{PF}_{6}\right]$ was used for collecting and separation nanoparticles of CNTs@DTG from blood samples.

\section{Experimental}

\subsection{Apparatus}

Chromium determination was done based on a spectra electrothermal atomic absorption spectrometer (ET-AAS, GBC 932, Aus.) by a graphite furnace accessory. All operating parameters were set based on manufacturer book of GBC. A multi hollow cathode lamp (MHCL) with a current of $6 \mathrm{~mA}$, wavelength of $357.9 \mathrm{~nm}$ with $0.2 \mathrm{~nm}$ slit was adjusted. All volumes from 20 to $100 \mu \mathrm{L}$ were injected to furnace tubes by auto-sampler 3000. The instrumental and extraction conditions are listed in Table 1. The temperature programming for chromium was shown in Table 2. The $\mathrm{pH}$ of the solutions and human samples were tuned by a digital $\mathrm{pH}$ meter (Metrohm 744). Microwave digestions were carried out with a multiwave 3000 (Anton Paar, $100 \mathrm{~mL}, 20$ bar; Austria). The ICP-MS (Perkin Elmer, USA) as ultra-trace analysis with high sensitivity was used for determining of chromium ions in human blood samples $(1200 \mathrm{~W}$; $1.0 \mathrm{~L} \mathrm{~min}^{-1} ; 2.0 \mathrm{sec}$ per mass; auxiliary gas $1.2 \mathrm{~L} \mathrm{~min}^{-}$ $\left.{ }^{1}\right)$. An ultrasonic bath for molecular biology such as blood samples with temperature controlling in realtime was prepared (Thomas, HB120 LED digital dry bath, USA).

Table 1. Instrumental conditions for chromium by ET-AAS

\begin{tabular}{ll}
\hline Parameters & Values \\
\hline Wavelength & $357.9 \mathrm{~nm}$ \\
Slit & $0.2 \mathrm{~nm}$ \\
Lamp current & $6 \mathrm{~mA}$ \\
Injection mode & Automatic \\
Volume Injection & $20 \mu \mathrm{L}$ \\
Mode & Peak Area \\
\hline
\end{tabular}


Table 2. The temperature program for chromium determination by ET-AAS

\begin{tabular}{ccccc}
\hline Step & Temperature $\left({ }^{\circ} \mathbf{C}\right)$ & Ramp time (s) & Hold time (s) & Ar flow rate $\left(\mathbf{m L ~}\right.$ min $\left.^{-1}\right)$ \\
\hline Dry & 120 & 15 & 15 & 300 \\
Ash & 1150 & 30 & 15 & 300 \\
Atomize & 2500 & 1 & 2 & 0.0 \\
Clean & 2600 & 1 & 2 & 300 \\
\hline
\end{tabular}

\subsection{Reagents and materials}

All reagents with ultra-trace analytical grade purchased from Merck, Germany. Cr(III) and Cr(VI) stock solution were prepared from an appropriate amount of the nitrate salt of this analytes as $1000 \mathrm{mg}$ $\mathrm{L}^{-1}$ solution in $0.02 \mathrm{~mol} \mathrm{~L}^{-1} \mathrm{HNO}_{3}$ (Merck). Standard solutions were prepared daily by dilution of the stock solution. The dithioglycerol material (DTG, CAS. N: 59-52-9) was purchased from Sigma Aldrich, Germany. The buffer solution was $0.3 \mathrm{~mol} \mathrm{~L}^{-1}$ $\mathrm{CH}_{3} \mathrm{COOH}$ adjusted to $\mathrm{pH} 5.5-6.0$ with $0.14 \mathrm{~mol} \mathrm{~L}^{-1}$ of $\mathrm{NaOH}$ solutions (Merck). The $\mathrm{pH}$ was adjusted to $0.2 \mathrm{molL}^{-1}$ of sodium phosphate buffer solution from the $\mathrm{pH}$ of 5.5 to $8.2\left(\mathrm{Na}_{2} \mathrm{HPO}_{4} / \mathrm{NaH}_{2} \mathrm{PO}_{4}\right)$. TX-100 as the anti-sticking agent, $\mathrm{HNO}_{3}, \mathrm{HCl}$, and acetone were purchased from Merck. Ultrapure water (18 $\mathrm{M} \Omega . \mathrm{cm}$ ) was prepared from Millipore Water System (Bedford, USA), and 1-octyl-3-methylimidazolium hexafluorophosphate ([OMIM] $\left[\mathrm{PF}_{6}\right]$ ) was prepared from Sigma Aldrich (Germany).

\subsection{Sample preparation of human blood}

For sampling, all glass tubes were washed with a $1.0 \mathrm{~mol} \mathrm{~L}^{-1} \mathrm{HNO}_{3}$ solution for one day and thoroughly rinsed for 6 times with DW. As chromium, concentrations in human blood are very low, even minor contamination at any step of sampling, storage and analysis has the potential to affect on the accuracy of the results. For analysis in human blood samples, $20 \mu \mathrm{L}$ of pure heparin (not chromium) was added to a $5 \mathrm{~mL}$ blood sample. The human blood sample was maintained at -20 ${ }^{\circ} \mathrm{C}$ in a PVC tube. The world medical association declaration of Helsinki (WMADH) in human blood samples was considered for sampling and analysis with permit form for all patients.

\subsection{Synthesis of CNTs@DTG}

First, the CNTs@COOH was prepared according to the acid oxidation method [26] and the CNTs@ $\mathrm{COOH}$ convert to CNTs@OH by Sodium borohydride. Then, the $0.5 \mathrm{~g}$ of CNTs@OH and 40 $\mathrm{mL}$ of dry xylene were sonicated for 15 minutes in a $100 \mathrm{~mL}$ round-bottomed flask (RBF). Then, the 3 $\mathrm{mL}$ of (3-chloropropyl) trimethoxysilane (CPTMS) was added to the mixture. After sonicating, the resulting mixture was refluxed at $60{ }^{\circ} \mathrm{C}$ under $\mathrm{N}_{2}$ atmosphere to remove the produced $\mathrm{HCl}$. The product of CNTs@Cl was cooled down to room temperature, and then filtered and washed with ethanol. In a 100 mL RBF, 1 g of CNTs@Cl and 1 $\mathrm{mL}$ of DTG were mixed in $60 \mathrm{~mL}$ ethanol using an ultrasonic bath. Then, a few drops of triethylamine were added to the above slurry, and the mixture was refluxed at $60^{\circ} \mathrm{C}$ for $3 \mathrm{~h}$. The product was separated from the reaction mixture by a PTFE membrane filter and washed with ethanol three times and finally dried under vacuum at $100{ }^{\circ} \mathrm{C}$ (Fig. 1).

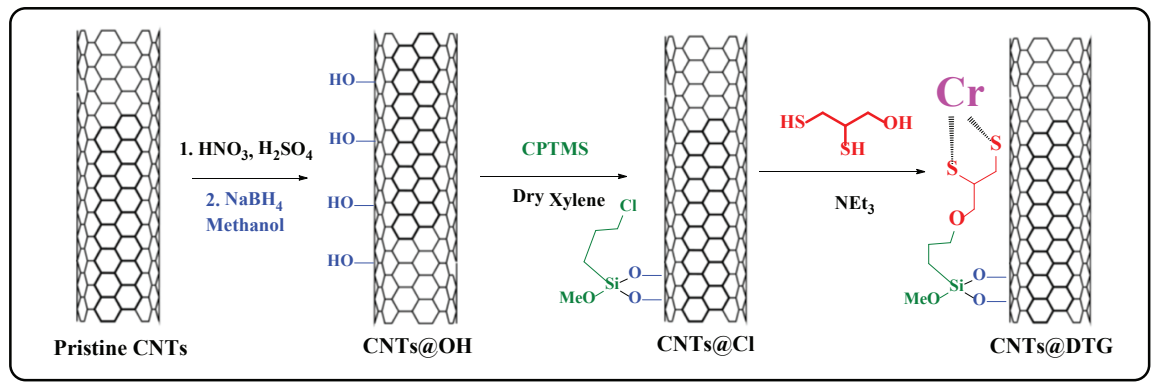

Fig. 1. Representation of the formation of CNTs@DTG. 


\subsection{The extraction procedure}

By D- $\mu$-SPBE method, $5 \mathrm{~mL}$ of human blood samples were used for speciation and determination of $\mathrm{Cr}$ (III) and $\mathrm{Cr}$ (VI) at optimized pH. By procedure, the mixture of $25 \mathrm{mg}$ of CNTs@DTG adsorbent, [OMIM] $\left[\mathrm{PF}_{6}\right]$ as hydrophobic IL and acetone added to standard and human blood samples with $\mathrm{Cr}$ (III) and $\mathrm{Cr}$ (VI) concentration between 0.05-1.8 $\mu \mathrm{g} \mathrm{L}^{-1}$ at $\mathrm{pH}=6$ and 2, respectively. After sonication for $3.0 \mathrm{~min}$, the $\mathrm{Cr}$ (III) and $\mathrm{Cr}$ (VI) ions were extracted with the HS group of CNTs@DTG (as a dative covalent bond) in optimized $\mathrm{pH}(\mathrm{pH}=6$; $\mathrm{CrIII} \rightarrow:$ :(SH-SH)@CNTs) (pH=2; CrVI $\rightarrow^{+}:\left(\mathrm{SH}_{2}-\right.$ $\left.\left.\mathrm{SH}_{2}\right) @ \mathrm{CNTs}\right)$. After extraction, the nanoparticles of CNTs@DTG were trapped in [OMIM] $\left[\mathrm{PF}_{6}\right]$ in the bottom of the conical tube by centrifuging samples for $5 \mathrm{~min}$. The upper phase was removed and then, the $\mathrm{Cr}$ (III) and $\mathrm{Cr}$ (VI) ions back-extracted from adsorbent in acidic $\mathrm{pH}\left(\mathrm{HNO}_{3}, 1 \mathrm{M}, 0.1 \mathrm{~mL}\right)$ for $\mathrm{Cr}$ (III) and basic $\mathrm{pH}(\mathrm{NaOH}, 0.5 \mathrm{M}, 0.1 \mathrm{~mL})$ for $\mathrm{Cr}$ (VI), respectively. Finally, the remained solution determined by ET-AAS after diluted with DW up to $0.2 \mathrm{~mL}$. The total chromium (T-Cr) was simply calculated by summarizing $\mathrm{Cr}$ (III) and $\mathrm{Cr}$ (VI) content (Table 3). The procedure used for a 10 blank solutions by $\mathrm{D}-\mu$-SPBE method. The enrichment factor (EF) calculated by curve fitting of calibration curves before and after preconcentration process $\left(\operatorname{tga}=\mathrm{m}_{1} / \mathrm{m}_{2}\right)$. Validation of method followed by ICPMS and CRM for chromium in real samples.

Table 3. Extraction conditions based on CNTs@DTG by D- $\mu$-SPBE procedure

\begin{tabular}{ll}
\hline Fathers & Values \\
\hline Working $\mathrm{pH}$ of $\mathrm{Cr}(\mathrm{III})$ & 6.0 \\
Working pH of $\mathrm{Cr}(\mathrm{VI})$ & 2.0 \\
Sample volume of D- $\mu$-SPBE & $5 \mathrm{~mL}$ \\
Linear range of D- $\mu$-SPBE & $0.12-3.88 \mu \mathrm{g} \mathrm{L}-1$ \\
Correlation coefficient & $\mathrm{R}=0.9996$ \\
Volume of Triton X-100 & $30 \mu \mathrm{L}$ \\
Volume of back-extraction (eluent) & $0.5 \mathrm{~mL}$ \\
Concentration of back-extraction $\left(\mathrm{HNO}_{3}, \mathrm{NaOH}\right)$ & $1 \mathrm{and} 0.5 \mathrm{~mol} \mathrm{~L}^{-1}$ \\
Amount of IL & $100 \mu \mathrm{L}, 0.1 \mathrm{~g}$ \\
Volume of dispersant solvent (Acetone) & $500 \mu \mathrm{L}$ \\
Shaking time & $3 \mathrm{~min}$ \\
Centrifugation time & $5 \mathrm{~min}$ \\
\hline
\end{tabular}

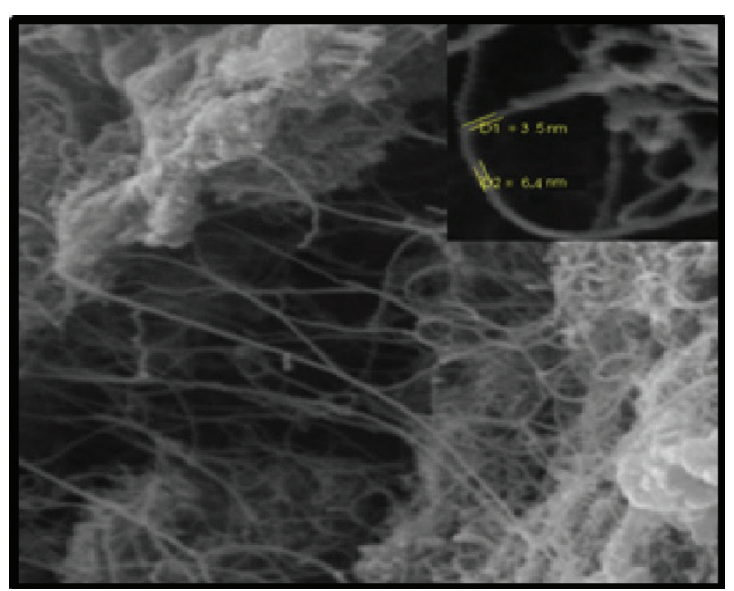

Fig.2. The SEM of CNTs@DTG adsorbent

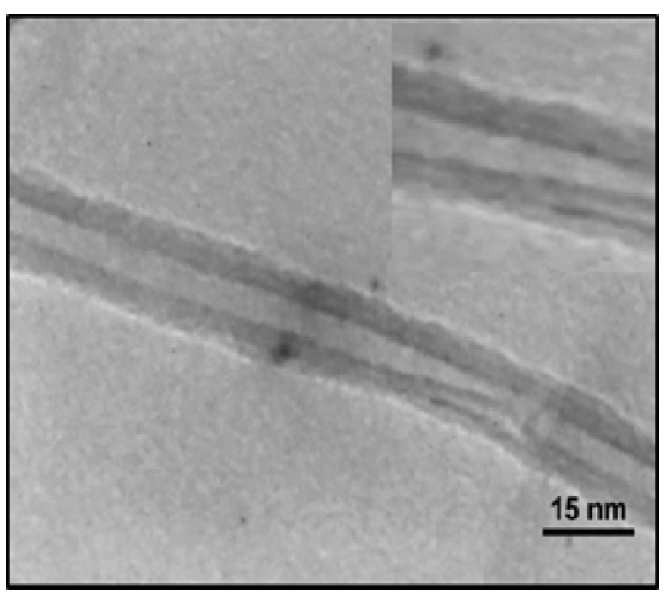

Fig.3. The TEM of CNTs@DTG adsorbent 


\section{Results and discussion}

\subsection{Characterizations}

The hydroxyl-functionalized CNTs are used for the synthesis of CNTs@DTG adsorbent. The SEM and TEM of CNTs@DTG showed low nanoparticles size about $80 \mathrm{~nm}$, that was showed in Figures 2 and 3, respectively.

The FT-IR spectrum of CNTs@DTG shows an absorption band corresponding to the $\mathrm{C}=\mathrm{C}$ bond at $1570 \mathrm{~cm}^{-1}$. The $\mathrm{C}=\mathrm{O}$ stretching vibration band of the OH-functionalized CNTs was seen at 1722 $\mathrm{cm}^{-1}$ corresponding to the primary $\mathrm{COOH}$ group of the CNTs. Figure 4 saw the absorption band of the $\mathrm{O}-\mathrm{Si}-\mathrm{O}$ in adsorbent seen at $1110 \mathrm{~cm}^{-1}$. Moreover, the absorption bands at the range of 2500-3000 $\mathrm{cm}^{-1}$ related to $\mathrm{C}-\mathrm{H}$ bond, which indicates the successful functionalization of CNTs with Clalkylsilane material. The appearance of a band at $2625 \mathrm{~cm}^{-1}$ confirms the presence of HS groups in the CNTs@DTG adsorbent.

\subsection{Effect of ETAAS conditions}

For increasing accuracy and repeatability of the procedure, the triton $\mathrm{X}-100$ was used in human blood samples. First, we selected a drying time of $30 \mathrm{~s}$ for water evaporation with $40 \mathrm{~s}$ of ramp time. Then, the effect of pyrolysis temperature on
Abs was studied within a range of $600-1400{ }^{\circ} \mathrm{C}$. The maximum Abs was obtained from 1000 to $1200{ }^{\circ} \mathrm{C}$. So, $1150{ }^{\circ} \mathrm{C}$ was selected as the optimum point. Also, the effect of atomization on chromium determination was examined between $2000-3000{ }^{\circ} \mathrm{C}$, and the maximum signal was obtained at $2.500{ }^{\circ} \mathrm{C}$. Cleaning time and temperature were ordered at $3 \mathrm{~s}$ and $2.600{ }^{\circ} \mathrm{C}$, respectively with Ar flow rate of 300 $\mathrm{mL} \min ^{-1}$.

\subsection{Effect of $\mathrm{pH}$ on the extraction}

The influence of $\mathrm{pH}$ on adsorption of $\mathrm{Cr}$ (III) and Cr (VI) ions on CNTs@DTG was investigated in different $\mathrm{pH}$ between $2-11$ for $1.0 \mu \mathrm{g} \mathrm{L}^{-1}$ of chromium concentration. The chemical and physical adsorption was strongly conditioned by the $\mathrm{pH}$ of solutions. The results show that the highest extraction efficiency for $\mathrm{Cr}(\mathrm{VI})$ was achieved in $\mathrm{pH}$ ranges from 1 to 3 , but the recovery values for $\mathrm{Cr}$ (III) were below $5 \%$ in this $\mathrm{pH}$. On the other hand, the efficient extraction for $\mathrm{Cr}$ (III) was achieved in $\mathrm{pH}$ ranges from 5 to 7 , but the recovery values for $\mathrm{Cr}$ (VI) were below 5\%. Thus, the procedure was applied to the speciation of two forms of chromium at $\mathrm{pH} 2$ and 6 as optimum points for $\mathrm{Cr}$ (VI) and $\mathrm{Cr}$ (III) extraction, respectively, by $\mathrm{D}-\mu-\mathrm{SPBE}$ procedure (Fig. 5).

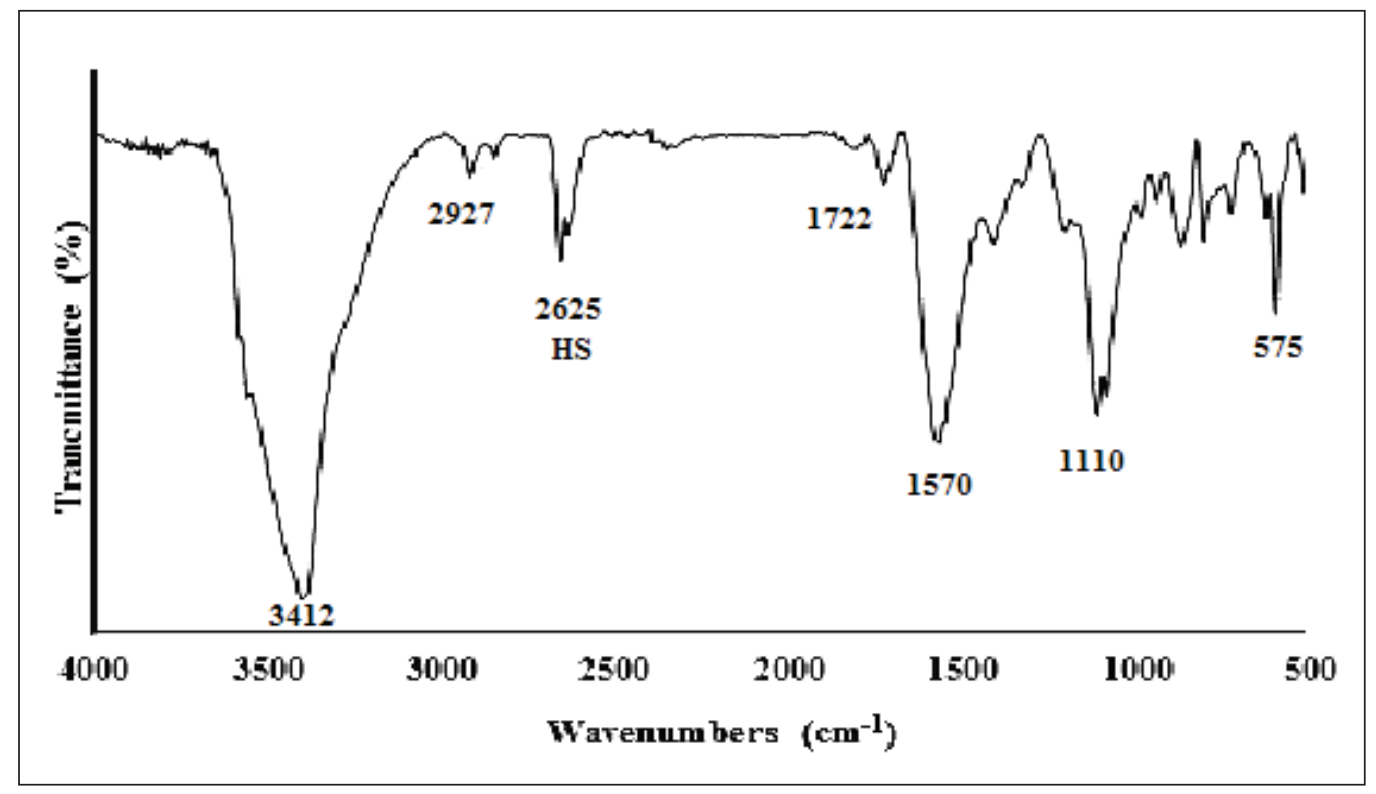

Fig.4. The FTIR of CNTs@DTG adsorbent 


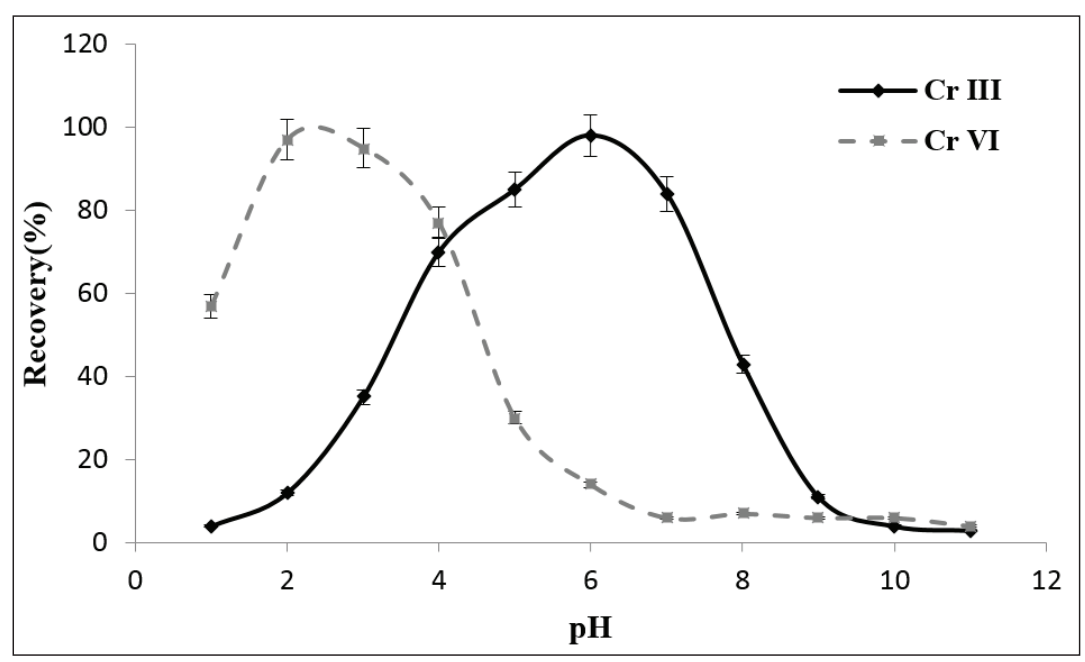

Fig. 5. The effect of $\mathrm{pH}$ on extraction and speciation of $\mathrm{Cr}$ (III) and $\mathrm{Cr}(\mathrm{VI})$ based on CNTs@DTG adsorbent by the D- $\mu$-SPBE procedure

\subsection{Effect of sample volume and amount of ionic liquid}

Sample volume is one of the most important parameters to be studied. The effect of sample volume between $2-20 \mathrm{~mL}$ was studied for 1.0 $\mu \mathrm{g} \mathrm{L}^{-1}$ of Cr (III) and Cr (VI) ions. Quantitative extraction was observed between $2 \mathrm{ml}$ and $10 \mathrm{ml}$. The recovery was decreased by more than $10 \mathrm{~mL}$ of blood samples. Moreover, in high sample volumes, the ionic liquid is partially solubilized in the liquid phase and leads to non-reproducible results. Therefore, a sample volume of $5 \mathrm{~mL}$ was selected for further works by D- $\mu$-SPBE procedure (Fig. 6). On the other hand, the extraction efficiency of the procedure was remarkably dependent on the ionic liquid amount as a separating phase. So, the amount of [OMIM][PF 6 , [HMIM][PF6] and [EMIM][PF6] as hydrophobic ILs was studied between 0.05-0.2 g. The results showed us, and the quantitative extraction was obtained more than $0.08 \mathrm{~g}$ of $[\mathrm{OMIM}]\left[\mathrm{PF}_{6}\right]$. Therefore, the amount of $0.1 \mathrm{~g}$ was selected as optimum mass for ionic liquid for collecting and separating CNTs@DTG from the liquid phase (Fig. 7).

\subsection{Effect of CNTs@DTG mass}

By procedure, the amount of CNTs@DTG adsorbent studied and optimized. Therefore, the amounts of

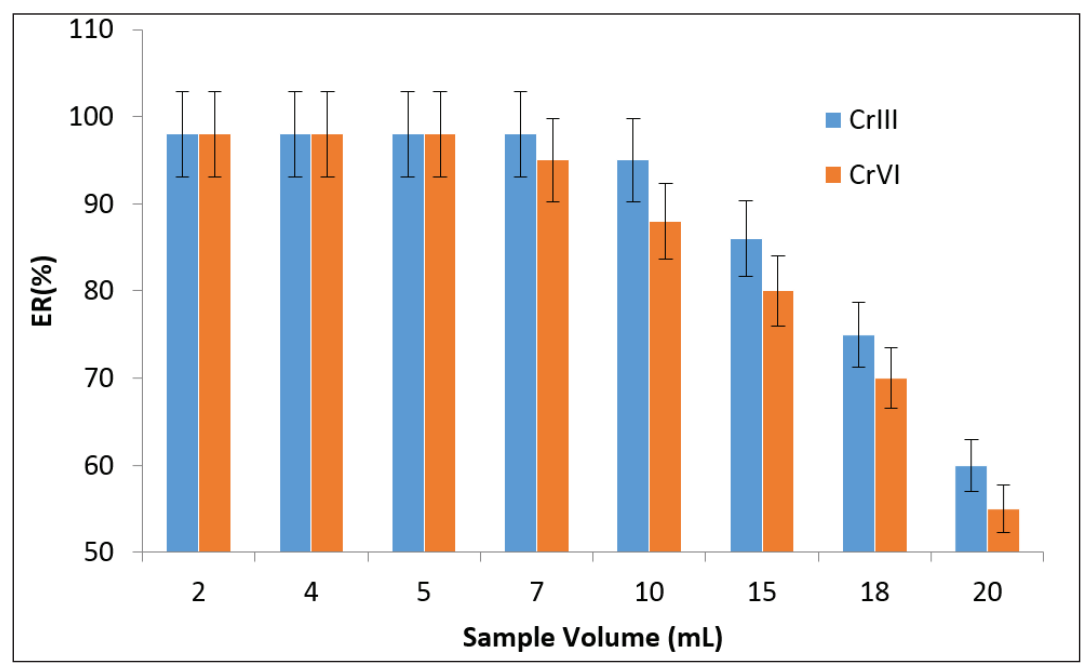

Fig. 6. The effect of sample volume on extraction and speciation of Cr (III) and Cr (VI) based on CNTs@DTG adsorbent by the D- $\mu$-SPBE procedure 


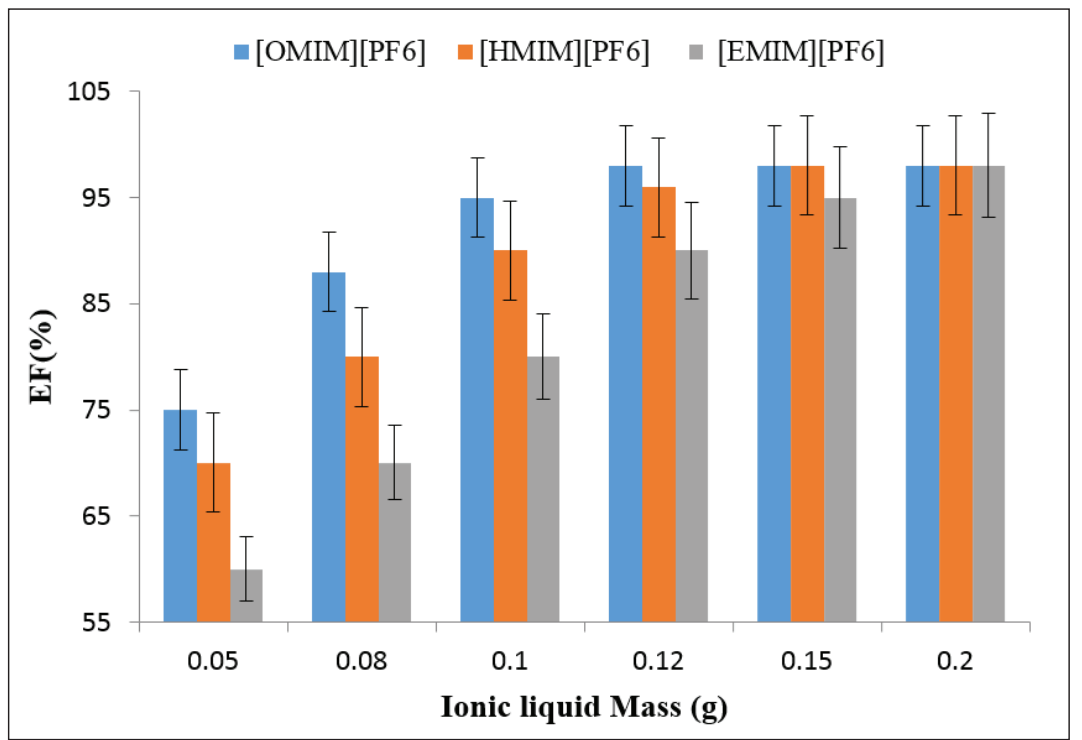

Fig. 7. The effect of ionic liquids mass on extraction and speciation of Cr (III) and Cr (VI) based on CNTs@DTG adsorbent by the D- $\mu$-SPBE procedure

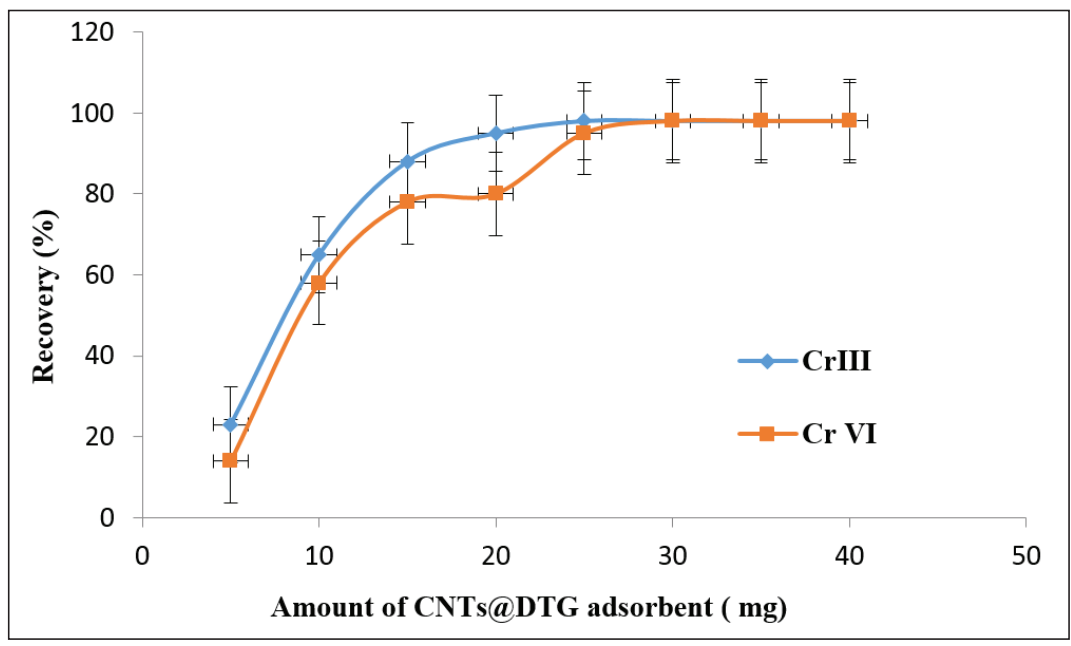

Fig. 8. The effect of CNTs@DTG mass on extraction and speciation of $\mathrm{Cr}$ (III) and $\mathrm{Cr}$ (VI) by the D- $\mu$-SPBE procedure

CNTs@DTG adsorbent between 5-35 mg were examined for $\mathrm{Cr}$ (III) and $\mathrm{Cr}$ (VI) extraction by the D- $\mu$-SPBE procedure. Based on results, the quantitative recoveries in human blood samples were obtained with 20 mg and 25 of CNTs@DTG for Cr (III) and $\mathrm{Cr}$ (VI) extraction, respectively. So, $25 \mathrm{mg}$ of CNTs@DTG was used as an optimum mass for D- $\mu$ SPBE procedure (Fig. 8).

\subsection{Effect of eluent on recovery}

The $\mathrm{Cr}$ (III) and $\mathrm{Cr}$ (VI) were back-extracted from CNTs@DTG sorbent based on changing pH by D- $\mu-$ SPBE procedure. By decreasing and increasing the
$\mathrm{pH}$, the covalence bonding in $\mathrm{Cr}$ (III) and $\mathrm{Cr}$ (VI) dissociate and release into the liquid phase. Different mineral reagents such as $\mathrm{NaOH}, \mathrm{HCl}, \mathrm{HNO}_{3}$, $\mathrm{H}_{2} \mathrm{SO}_{4}$ were selected for investigating of chromium back-extraction from the CNTs@DTG/IL phase. The research showed that $1 \mathrm{~mol} \mathrm{~L}^{-1}$ of $\mathrm{HNO}_{3}$ and $0.5 \mathrm{~mol} \mathrm{~L}^{-1}$ of $\mathrm{NaOH}$ quantitatively extracted $\mathrm{Cr}$ (III) and Cr (VI) from the CNTs@DTG/IL phase.

\subsection{Effect of interference ions on extraction}

By procedure, the interference ions can be affected by the extraction chromium in blood samples. Due to human blood samples, the most probable 
Table 4. The effect of matrix ions on the determination of $\mathrm{Cr}$ (III) and $\mathrm{Cr}(\mathrm{VI})$ by $\mathrm{D}-\mu$-SPBE procedure

\begin{tabular}{lllll}
\hline Ions & \multicolumn{2}{c}{$\begin{array}{c}\text { Maximum tolerance ratio } \\
\text { (matrix ion conc./Cr conc.) }\end{array}$} & & Recovery (\%) \\
\cline { 2 - 6 } & $\mathbf{C r}$ (VI) & $\mathbf{C r}$ (III) & $\mathbf{C r}$ (VI) & $\mathbf{C r}$ (III) \\
\hline $\mathrm{K}^{+}, \mathrm{Na}^{+}, \mathrm{Li}^{+}, \mathrm{Ca}^{2+}, \mathrm{Mg}^{2+}$ & 1100 & 900 & 97.4 & 98.3 \\
\hline $\mathrm{Mn}^{2+}, \mathrm{Cu}^{+2}, \mathrm{Zn}^{2+}$ & 850 & 700 & 98.2 & 96.5 \\
\hline $\mathrm{Cd}^{2+}, \mathrm{Pb}^{2+}$ & 500 & 600 & 99.2 & 97.7 \\
\hline $\mathrm{Cl}^{-}, \mathrm{F}^{-}, \mathrm{I}^{-}, \mathrm{NO}_{3}^{-}, \mathrm{CH} 3 \mathrm{COO}^{-}$ & 1200 & 1000 & 98.1 & 96.8 \\
\hline $\mathrm{PO}_{4}^{3-}, \mathrm{CO}_{3}^{2-}, \mathrm{SO}_{4}^{2-}$ & 900 & 750 & 97.5 & 98.2 \\
\hline $\mathrm{Ag}^{+}, \mathrm{Ni}^{2+}, \mathrm{Hg}^{2+}$ & 200 & 250 & 95.3 & 97.6 \\
\hline $\mathrm{Fe}^{3+}, \mathrm{V}^{3+}$ & 500 & 650 & 96.8 & 98.9 \\
\hline
\end{tabular}

metal ions in blood were selected for evaluating of potential interfering ions on the extraction of chromium. So, the $5 \mathrm{ml}$ of the sample containing $3.5 \mu \mathrm{gL}^{-1}$ of $\mathrm{Cr}$ (III) and $\mathrm{Cr}$ (VI) and 1-2 $\mathrm{mg} \mathrm{L}^{-1}$ of different ions in the matrix were used. The tolerate amounts of each ion had less than $5 \%$ of the absorbance alteration. The results showed interference ions do not decrease the extraction of chromium in optimized conditions. The results are shown in Table 4.

\subsection{Validation of D- $\mu$-SPBE procedure}

The D- $\mu$-SPBE method was applied to determine $\mathrm{Cr}$ (VI) and $\mathrm{Cr}$ (III) in $10 \mathrm{~mL}$ of human blood samples at $\mathrm{pH}$ of 2 and 6 , respectively. Since no standard reference material (CRM) for $\mathrm{Cr}$ (III) and $\mathrm{Cr}$ (VI) are currently available, So, ICP Ms analysis in blood samples as CRM wasused to spikereal samples(Table 5). Also, the spiked samples have demonstrated the reliability, precision and accuracy of the method for determination of $\mathrm{Cr}$ (III) and $\mathrm{Cr}$ (VI) in human blood samples by D- $\mu$-SPBE procedure (Table 6). The extraction efficiency of spiked samples is satisfactorily reasonable and was confirmed using the addition method, which indicates the capability of the system in the determination of $\mathrm{Cr}$ (VI) and $\mathrm{Cr}$ (III) in human blood samples. The calibration curve of the D- $\mu$-SPBE method was linear between 0.12$3.88 \mu \mathrm{g} \mathrm{L}^{-1}$ after the preconcentration process. The $\mathrm{Cr}$ (VI) enters to the cytoplasm of red blood cells (RBC) and is reduced to Cr(III) by Cys and ascorbic acid. So, the concentration of chromium in the red blood cells related to exposure of $\mathrm{Cr}$ (VI). Thus, the total concentration of $\mathrm{Cr}$ in blood was calculated by summarizing of $\mathrm{Cr}$ (VI) and $\mathrm{Cr}$ (III) which was determined by ET-AAS. Therefore, The Cr (VI) has a low concentration in serum or plasma samples as compared to blood samples.

Table 5. Method validation for chromium in human blood samples by ICP-MS and compared to the D- $\mu$-SPBE method $(n=5)$

\begin{tabular}{ccccc}
\hline${ }^{\mathrm{a}}$ Sample & Added $\left(\boldsymbol{\mu g} \mathbf{L}^{-1}\right)$ & ${ }^{*} \mathbf{I C P}-\mathrm{MS}\left(\boldsymbol{\mu g} \mathbf{L}^{-1}\right)$ & ${ }^{*}$ Found $\left(\boldsymbol{\mu g} \mathbf{L}^{-1}\right)^{\mathbf{a}}$ & Recovery $(\%)$ \\
\hline A & ------ & $1.22 \pm 0.02$ & $1.19 \pm 0.06$ & 97.5 \\
& 1.0 & ----- & $2.15 \pm 0.07$ & 96.0 \\
\hline B & ------ & $1.51 \pm 0.03$ & $1.54 \pm 0.08$ & 101.9 \\
& 1.5 & ----- & $2.97 \pm 0.14$ & 95.3 \\
\hline C & ------ & $2.04 \pm 0.05$ & $1.98 \pm 0.11$ & 97.1 \\
& 1.5 & ----- & $3.43 \pm 0.16$ & 96.6 \\
\hline D & ------ & $0.55 \pm 0.01$ & $0.58 \pm 0.02$ & 105.4 \\
& 0.5 & ----- & $1.06 \pm 0.05$ & 96.0 \\
\hline
\end{tabular}

${ }^{*}$ Mean of three determinations \pm confidence interval $(\mathrm{P}=0.95, \mathrm{n}=5)$

a A,B,C,D are real blood samples which analysis with ICP-MS as CRM of total chromium 
Table 6. Validation of chromium speciation based on CNTs@DTG in human serum and blood samples by D- $\mu$-SPBE method

\begin{tabular}{|c|c|c|c|c|c|c|c|}
\hline \multirow[t]{2}{*}{ Sample } & \multicolumn{2}{|c|}{$\left.\operatorname{Added}(\mu \mathrm{g} \mathrm{L})^{-1}\right)$} & \multicolumn{2}{|c|}{ Found $\left(\mu \mathrm{g} \mathrm{L}^{-1}\right)^{\mathrm{a}}$} & \multirow[t]{2}{*}{ Total $^{a}$} & \multicolumn{2}{|c|}{ Recovery (\%) } \\
\hline & $\mathrm{Cr}$ (III) & $\mathrm{Cr}$ (VI) & $\mathrm{Cr}$ (III) & $\operatorname{Cr}(\mathrm{VI})$ & & $\mathrm{Cr}$ (III) & $\mathrm{Cr}(\mathrm{V})$ \\
\hline \multirow[t]{3}{*}{ Blood } & --- & --- & $1.45 \pm 0.08$ & $0.26 \pm 0.02$ & $1.71 \pm 0.09$ & --- & --- \\
\hline & 1.5 & --- & $2.93 \pm 0.15$ & $0.24 \pm 0.01$ & $3.17 \pm 0.29$ & 98.6 & --- \\
\hline & --- & 0.2 & $1.47 \pm 0.09$ & $0.45 \pm 0.02$ & $1.92 \pm 0.11$ & --- & 95.0 \\
\hline \multirow[t]{3}{*}{ Blood } & --- & --- & $1.61 \pm 0.11$ & $0.76 \pm 0.03$ & $2.37 \pm 0.12$ & --- & --- \\
\hline & 1.5 & --- & $3.09 \pm 0.14$ & $0.73 \pm 0.04$ & $3.82 \pm 0.20$ & 98.7 & --- \\
\hline & --- & 1.0 & $1.59 \pm 0.10$ & $1.78 \pm 0.08$ & $3.36 \pm 0.18$ & --- & 102 \\
\hline \multirow[t]{3}{*}{ Serum } & --- & --- & $1.92 \pm 0.09$ & $0.14 \pm 0.01$ & $2.06 \pm 0.12$ & --- & --- \\
\hline & 1.5 & --- & $3.38 \pm \cdot, 19$ & $0.16 \pm 0.01$ & $3.56 \pm 0.16$ & 97.3 & --- \\
\hline & --- & 0.2 & $1.89 \pm \cdot, 10$ & $0.33 \pm 0.01$ & $2.22 \pm 0.11$ & --- & 95 \\
\hline
\end{tabular}

${ }^{\mathrm{a}}$ Mean of three determinations \pm confidence interval $(\mathrm{P}=0.95, \mathrm{n}=5)$

\section{Conclusion}

In this work, the $\mathrm{D}-\mu$-SPBE procedure combined with ET-AAS to develop a new procedure for the speciation and determination of trace amount of $\mathrm{Cr}$ (III) and Cr (VI) in blood samples. Moreover, the factors influencing the D- $\mu$-SPBE procedure such as; the sorbent mass, the sample volume, the amount of IL and $\mathrm{pH}$ were studied and optimized. The [OMIM][PF6] as hydrophobic ionic liquid helps to provide a reliable and efficient extraction for speciation of $\mathrm{Cr}$ (III) and $\mathrm{Cr}$ (VI) in blood samples as an environmentally friendly solvent for collecting of CNTs@DTG adsorbent from the liquid phase. The enrichment factor and recovery was 9.8 and $95-105 \%$, respectively. The limit of detections (LOD) of $32 \mathrm{ng} \mathrm{L}^{-1}$ and $28 \mathrm{ng} \mathrm{L}^{-1}$ for $\mathrm{Cr}$ (III) and $\mathrm{Cr}$ (VI) were achieved at pH 6 and 2, respectively. In this study, a simple, efficient extraction and sensitive procedure were used for speciation of $\mathrm{Cr}$ (III) and $\mathrm{Cr}$ (VI) in human blood samples in a short time as compared to other methods. The mean of $\mathrm{PF}$, reusability, RSD\%, and LOD were obtained 9.85, 24 times, 2.53 and $30 \mathrm{ng} \mathrm{L}^{-1}$ for $5.0 \mathrm{~mL}$ of human blood samples, respectively. Validation of the methodology was confirmed by spiking and ICP-Ms analysis as CRM to samples. The proposed procedure was successfully used to speciation and separation of Cr (III) and Cr (VI) in human blood samples.

\section{Acknowledgements}

The authors wish to thank Semnan University, Iran and the Department of Inorganic Chemistry, Faculty of Chemistry, University of Tabriz, Iran for supporting this work. The authors wish to thank the workers for their kindness and voluntary participation in this study. This study was supported by Semnan University by a grant and approved by the Ethics Committee of Semnan University (ECSU, Project No. 8051127-01). Before starting, the goals and stages of the study were explained to the participants and they were asked to sign the informed consent form.

\section{References}

[1] Y. Wang, H. Su, Carcinogenicity of chromium and chemoprevention: a brief update, Onco. Targets Ther., 10 (2017) 4065-4079.

[2] P. Singh, D.K. Chowdhuri, Environmental presence of hexavalent but not trivalent chromium causes neurotoxicity in exposed drosophila melanogaster, Mol Neurobiol., 54 (2017) 3368-3387.

[3] A. Swaroop, M. Bagchi, H.G. Preuss, S. Zafra-Stone, T. Ahmad, D. Bagchi, Benefits of chromium (III) complexes in animal and human health, the nutritional biochemistry of chromium (III), Cambridge, MA: Elsevier, pp. 251-78, 2019. 
[4] J.B. Vincent JB, New evidence against chromium as an essential trace element, J. Nutr., 147 (2017) 2212-2219.

[5] E.M. Hamilton, S.D. Young, E.H. Bailey, M.J. Watts, Chromium speciation in foodstuffs: A review, Food Chem., 250 (2018)105-12.

[6] K. Yatera, Y. Morimoto, S. Ueno, S. Noguchi, T. Kawaguchi, F. Tanaka, H. Suzuki, T. Higashi, Cancer risks of hexavalent chromium in the respiratory tract, J. UOEH., 40 (2018) 157-172.

[7] P.L. Abreu, T. Cunha-Oliveira, L.M.R. Ferreira, A.M. Urbano, Hexavalent chromium, a lung carcinogen, confers resistance to thermal stress and interferes wif heat shock protein expression in human bronchial epithelial cells, Biometals, 31 (2018) 477-487.

[8] World Health Organization. Inorganic Cr(VI) compounds., concise international chemical assessment document, Geneva, World Health Organization, 78, 2013.

[9] American Conference of Governmental Industrial Hygienists (ACGIH), U.S documentation of the threshold limit values and biological exposure indices, 7th Edition, 2011.

[10] Agency for Toxic Substances and Disease Registry (ATSDR), Chromium, public health service, US Atlanta GA, 2018.

[11] Q.y. Zhu, L.y. Zhao, Speciation analysis of chromium by carboxylic group functionalized mesoporous silica with inductively coupled plasma mass spectrometry, Talanta, 195 (2019) 173-180.

[12] A. Islam, H. Ahmad, N. Zaidi, S. Kumar, A graphene oxide decorated with triethylenetetramine-modified magnetite for separation of chromium species prior to their sequential speciation and determination via FAAS, Microchim. Acta, 183 (2016) 289296.

[13] T.S. Munonde, N.W. Maxakato, P.N. Nomngongo, Preconcentration and speciation of chromium species using ICP-OES after ultrasound-assisted magnetic solid phase extraction with an amino-modified magnetic nanocomposite prepared from $\mathrm{Fe}_{3} \mathrm{O}_{4}$, $\mathrm{MnO}_{2}$ and $\mathrm{Al}_{2} \mathrm{O}_{3}$, Microchim. Acta, 184 (2017) 1223- 1232.

[14] H. M. Huang, L. J. Zhao, B. S. Chen, B. Hu, Advanced functional materials in solid phase extraction for ICP-MS determination of trace elements and their species: A review, Anal. Chim. Acta, 973 (2017) 1-24.

[15] L.A. Meira, Multi-element determination of $\mathrm{Cd}, \mathrm{Pb}, \mathrm{Cu}, \mathrm{V}, \mathrm{Cr}$, and $\mathrm{Mn}$ in ethanol fuel samples using energy dispersive X-ray fluorescence spectrometry after magnetic solid phase microextraction using $\mathrm{CoFe}_{2} \mathrm{O}_{4}$ nanoparticles, J. Microchem., 142 (2018) 144-151.

[16] Z. Sarikhani, M. Manoochehri, Determination of Ultra Trace $\mathrm{Cr}(\mathrm{III})$ and $\mathrm{Cr}(\mathrm{VI})$ species by electrothermal atomic absorption spectrometry after simultaneous Magnetic solid phase extraction with the aid of a novel imidazolium-functionalized magnetite graphene oxide nanocomposite, Bull. Chem. Soc. Jpn., 90 (2017) 746-753.

[17] N. Campillo, P. Viñas, J. Sandrejova, V. Andruch, Ten years of dispersive liquidliquid microextraction and derived techniques, Appl. Spect. Rev., 52 (2017) 267-415.

[18] B. Hu, M. He, B. Chen, In solid phase extraction, (ed Colin, F. Poole) Elsevier, pp. 235-284, 2020.

[19] M. Ghorbani, M. Aghamohammad hassan, M. Chamsaz, H. Akhlaghi, T. Pedramrad, Dispersive solid phase microextraction, TrAC, Trends Anal. Chem., 118 (2019) 793-809.

[20] K. M. Diniz, C. R. Teixeira Tarley, Speciation analysis of chromium in water samples through sequential combination of dispersive magnetic solid phase extraction using mesoporous amino-functionalized $\mathrm{Fe}_{3} \mathrm{O}_{4} /$ $\mathrm{SiO}_{2}$ nanoparticles and cloud point extraction, J. Microchem., 123 (2015)185-195. 
[21] L. Zhiyong, Y. Feng, L. Xiaomin, W. Huiyong, P. Yuanchao, H.Q. Nimal Gunaratne, W. Jianji, Light-triggered switchable ionic liquid aqueous two-phase systems, ACS Sustain. Chem. Eng., 8 (2020) 15327-15335.

[22] S. M. Yousefi, F. Shemirani, Carbon nanotube-based magnetic bucky gels in developing dispersive solid-phase extraction: application in rapid speciation analysis of $\mathrm{Cr}(\mathrm{VI})$ and $\mathrm{Cr}(\mathrm{III})$ in water samples, Int. J. Environ. Anal. Chem., 97 (2017) 1065-1079.

[23] M. H. Mashhadizadeh, M. AmoliDiva, Atomic absorption spectrometric determination of $\mathrm{Al}^{3+}$ and $\mathrm{Cr}^{3+}$ after preconcentration and separation on 3-mercaptopropionic acid modified silica coated- $\mathrm{Fe}_{3} \mathrm{O}_{4}$ nanoparticles, J. Anal. At Spectrom., 28 (2013) 251-258.
[24] A. Saboori, A nanoparticle sorbent composed of MIL-101(Fe) and dithiocarbamatemodified magnetite nanoparticles for speciation of $\mathrm{Cr}(\mathrm{III})$ and $\mathrm{Cr}(\mathrm{VI})$ prior to their determination by electrothermal AAS, Microchim. Acta, 184 (2017) 15091516.

[25] S. Periyasamy, V.Gopalakannan, N. Viswana, Fabrication of magnetic particles imprinted cellulose based biocomposites for chromium(VI) removal, Carbohydr. Polym., 174 (2017) 352-359.

[26] M.B. HosseinAbadi, H. Shirkhanloo, J. Rakhtshah, The evaluation of TerphApm@ MWCNTs as a novel heterogeneous sorbent for benzene removal from air by solid phase gas extraction, Arab. J. Chem., 13 (2020) 1741-1751. 